\title{
Solid Waste Management in the Context of a Circular Economy in the MENA Region
}

\author{
Safwat Hemidat ${ }^{1, *}$, Ouafa Achouri ${ }^{2}{ }^{(D}$, Loubna El Fels ${ }^{3}$, Sherien Elagroudy ${ }^{4}$, Mohamed Hafidi ${ }^{3}{ }^{(}$, \\ Benabbas Chaouki ${ }^{5}$, Mostafa Ahmed ${ }^{4}$, Isla Hodgkinson ${ }^{6}{ }^{(1)}$ and Jinyang Guo ${ }^{7}$
}

1 Department of Waste and Resource Management, Rostock University, 18051 Rostock, Germany

2 Department of Environmental Engineering, Faculty of Process Engineering, University of Salah Boubnider Constantine 3, 'B' 72 Ali Mendjeli Nouvelle Ville, Constantine 25000, Algeria; ouafa.achouri@univ-constantine3.dz

3 Laboratory of Microbial Biotechnologies, Agrosciences and Environment (BioMAgE) Labeled Research Unit-CNRST N ${ }^{\circ}$ 4, Cadi Ayyad University, Marrakesh 40000, Morocco; loubna.elfels@gmail.com (L.E.F.); hafidi@uca.ac.ma (M.H.)

4 Egypt Solid Waste Management Center of Excellence, Faculty of Engineering, Ain Shams University, Abbasseya, Cairo Governorate 11535, Egypt; s.elagroudy@eng.asu.edu.eg (S.E.); mostafa.sattar@gmail.com (M.A.)

5 Institute of Urban Techniques Management, Constantine 3 University, 'B' 72 Ali Mendjeli Nouvelle Ville, Constantine 25000, Algeria; benabbas.chaouki@gmail.com

6 Institute of Waste Management and Circular Economy, Technical University of Dresden, 01069 Dresden, Germany; isla_marie.hodgkinson@tu-dresden.de

7 Sustainable Resource and Waste Management, Hamburg University of Technology, Blohmstr. 15, 21079 Hamburg, Germany; jy.guo@tuhh.de

* Correspondence: safwat.hemidat2@uni-rostock.de

check for updates

Citation: Hemidat, S.; Achouri, O.; El Fels, L.; Elagroudy, S.; Hafidi, M.; Chaouki, B.; Ahmed, M.; Hodgkinson, I.; Guo, J. Solid Waste Management in the Context of a Circular Economy in the MENA Region. Sustainability 2022, 14, 480. https://doi.org/10.3390/su14010480 Academic Editors: Hani Abu-Qdais, Anna Kurbatova and Caterina Picuno

Received: 23 November 2021 Accepted: 30 December 2021 Published: 3 January 2022

Publisher's Note: MDPI stays neutral with regard to jurisdictional claims in published maps and institutional affiliations.

Copyright: (C) 2022 by the authors. Licensee MDPI, Basel, Switzerland. This article is an open access article distributed under the terms and conditions of the Creative Commons Attribution (CC BY) license (https:// creativecommons.org/licenses/by/ $4.0 /)$.

\begin{abstract}
Solid waste management in most MENA countries is characterized by lack of planning, improper disposal, inadequate collection services, inappropriate technologies that suit the local conditions and technical requirements, and insufficient funding. Therefore, waste management is mainly limited to collection, transportation, and disposal. As the circular economy has recently been given high priority on the MENA region's political agenda, all MENA member states are seeking to move away from old-fashioned waste disposal, "waste management", towards a more intelligent waste treatment, "resource efficiency". This paper presents a comprehensive overview of national systems for municipal solid waste (MSW) management, and material and energy recovery as an important aspect thereof, in the context of the circular economy in selected countries in the MENA region. Since policy, regulation, and treatment technologies are traditionally connected to MSW management, the focus of this article is twofold. Firstly, it aims to identify the different practices of solid waste management employed in selected MENA region countries and their approaches to embracing the circular economy and, secondly, it examines the extent to which policies and technologies applied play any role in this context. The study revealed that most waste management issues in the countries analyzed appear to be due to political factors and the decentralized nature of waste management with multi-level management and responsibilities. In fact, material and energy recovery in the context of municipal solid waste management does not differ significantly in the countries in the MENA region considered. In most cases, "waste" is still seen as "trouble" rather than a resource. Therefore, a fresh vision on how the solid waste management system can be transformed into a circular economy is required; there is a need for paradigm shift from a linear economy model to a circular-economy model.
\end{abstract}

Keywords: solid waste management (SWM); legal framework; financial framework; treatment technologies and disposal; MENA region 


\section{Introduction}

The MENA region covers an area of more than 15 million square kilometers and has about six percent of the world's population, equivalent to the population of the European Union (EU). The total population of the region has increased from about 100 million in 1950 to about 465 million in 2020 [1,2].

The MENA region is characterized by its dependence on its non-renewable resources It includes 20 countries, with a total population of about 465 million (Table 1). The three smallest countries, Bahrain, Djibouti, and Qatar, each have populations of 1.7 million, 1.0, and 2.9 million, respectively. In contrast, the two largest countries, Egypt and the Islamic Republic of Iran, have about 102 and 84 million people, respectively. Along with Algeria, Morocco, and Sudan, these five most populous countries account for about $70 \%$ of the region's population. About half of the population lives in cities [1].

Table 1. Population of MENA region countries [1].

\begin{tabular}{cccc}
\hline $\begin{array}{c}\text { MENA Member } \\
\text { Country }\end{array}$ & $\begin{array}{c}\text { Population } \\
\text { in Million } \\
\text { Inhabitants }\end{array}$ & $\begin{array}{c}\text { MENA Member } \\
\text { Country }\end{array}$ & $\begin{array}{c}\text { Population } \\
\text { in Million } \\
\text { Inhabitants }\end{array}$ \\
\hline Egypt & 102 & UAE & 9.8 \\
Iran & 84 & Israel & 9 \\
Algeria & 44 & Lebanon & 7 \\
Iraq & 40 & Libya & 7 \\
Morocco & 37 & Oman & 5 \\
Saudi Arabia & 35 & West Bank \& Gaza & 4.8 \\
Yemen & 30 & Kuwait & 4 \\
Syria & 17.5 & Qatar & 2.9 \\
Tunisia & 12 & Bahrain & 1.7 \\
Jordan & 10.2 & Djibouti & 1 \\
\hline
\end{tabular}

Currently, solid waste management (SWM) is one of the most important environmental challenges facing countries in the Middle East and North Africa (MENA) region. This is attributed to the rapid growth of the population, a booming economy, rapid urbanization, and high standards of living in the community, which have significantly accelerated the rate of solid waste generation $[3,4]$. The provision of an efficient and sustainable waste management system that takes into account the potential impact on public health and the environment is critical to most governments in the region.

In general, the waste resource sector across the region is insufficiently regulated. Notwithstanding continuous attempts, most countries in the MENA region have not yet put in place appropriate long-term legislation and strategies in the field of waste management and the circular economy [4]. The waste management system in the region faces many obstacles, for example, but not limited to, lack of planning, centralization of authority at the national level, overlapping of powers and responsibilities, lack of coordination between relevant institutions and ministries, insufficient cost recovery mechanisms, lack of trained and skilled personnel, inequality in service between rural and urban areas, and the lack of reliable databases $[5,6]$. The inability of the existing waste management systems and municipal administrations to cope with the growing waste-generation rates and the pressures placed on waste infrastructure has led to significant health and environmental problems in the region. Demand for municipal services continues to outstrip the capacity of systems and infrastructure that have already seen years or even decades of underinvestment, unreliability, and high costs $[7,8]$.

Despite the fact that, recently, many countries in the MENA region have introduced the concept of Integrated Solid Waste Management (ISWM), to date, there have been no tangible results in terms of reducing the amount of waste that is landfilled or dumped. The latter remains the primary waste disposal practice in most MENA countries, being poorly managed and lacking most basic engineering and sanitary procedures for collecting and treating gas and leachate. However, collection and sorting, composting, incineration of 
medical waste, and sanitary landfills are starting to be practiced, while recycling, reuse, and resource recovery are still in the initial stages [7-9]. Against this background, a fresh look is required and there is a need for a new a joint vision on how the solid waste management system can be transformed into a circular economy. Being the main drivers of the transition towards a sustainable waste management system, the policies, strategies, and practices in place that regulate the performance of waste management in the region should be comprehensively reviewed. To this end, the aim of this study was to identify the different practices of solid waste management employed in selected MENA region countries and their approaches to embracing the circular economy. A further objective was to examine the extent to which the applied waste management policies, regulations, and technologies play any role in the context of circular economy.

\section{Municipal Solid Waste Generation and Composition in MENA Region Countries}

The definition of municipal solid waste (MSW) can vary widely between countries. Typically, the term municipal solid waste refers to solid waste generated from community activities (for example, residential, commercial, institutional, and industrial). While construction waste and hazardous waste are excluded from MSW in European countries, they are considered to be domestic solid waste in most developing countries [10]. Municipal solid waste is commonly called waste, garbage, trash, or refuse; hence, waste refers to the waste generated from several activities.

The amount of MSW generated by developing countries is about 120 million tons per year. This amount was generated by 16 countries (Table 2). The average values of waste generation per capita in developing countries are relatively low, ranging from 0.5 to $1.1 \mathrm{~kg}$ /capita/day, compared to those countries in the Organization for Economic Cooperation and Development (OECD) with an average value of $2.2 \mathrm{~kg}$ per capita per day [4].

Table 2. Municipal solid waste amount in the MENA region.

\begin{tabular}{ccccccc}
\hline \multirow{2}{*}{ Country } & \multicolumn{2}{c}{ Waste kg/Day } & \multirow{2}{*}{$\begin{array}{c}\text { Waste Volume } \\
\text { Million Ton/Year }\end{array}$} & \multicolumn{2}{c}{ Disposal Route \% } \\
\cline { 2 - 3 } & Large City & Rural & & Recovery & Landfilling \\
\hline Egypt & 0.85 & 0.5 & 26.0 & 10 & 90 \\
Algeria & 0.8 & 0.6 & 13.5 & 8 & 92 \\
Bahrain & 2.7 & 1.1 & 0.8 & 5 & 95 \\
Iraq & 1.4 & 0.85 & 12.8 & 5 & 95 \\
Yemen & 0.6 & 0.35 & 3.8 & 7 & 93 \\
Jordan & 0.9 & 0.6 & 3.4 & 7 & 93 \\
Kuwait & 1.5 & 1.4 & 1.6 & 10 & 90 \\
Lebanon & 0.95 & 0.8 & 2.04 & 23 & 77 \\
Libya & 1.12 & 0.85 & 3.2 & 3 & 97 \\
Morocco & 0.76 & 0.3 & 7.4 & 9 & 91 \\
Qatar & 2.5 & 0.6 & 1.5 & 10 & 90 \\
Oman & 1.3 & 0.7 & 2.5 & 5 & 95 \\
Saudi & 1.8 & 1.5 & 18 & 12 & 88 \\
Arabia & & & & 25 & 75 \\
Syria & 0.5 & 0.4 & 3.6 & 9 & 91 \\
Tunisia & 0.8 & 0.5 & 2.5 & 27 & 73 \\
UAE & 1.47 & 1.2 & 8.5 & &
\end{tabular}

Having accurate and reliable data on waste composition is a critical factor for waste management and utilization options. Moreover, the process of selecting an approach for MSW management and treatment (recycling, energy recovery, etc.) is strongly influenced by the composition, characteristics, and composition of the waste. Thus far, these required data are not available in many developing countries, and if available they are in many cases inconsistent. Moreover, most of the available data are based on theoretical estimation rather than actual measurements [11,12].

A full description of the amount of waste generated and its composition in the four targeted MENA region countries is provided next. 


\subsection{Algeria}

Given its surface area, Algeria is a large country; it is ranked tenth-largest in the world by size. However, it has a very varied population distribution, with high population densities in the north and very low in the south. The economic activities are concentrated in urban areas and large metropolises; consequently, there is a major difference in the waste generation between the cities in the country [13].

The total amount of municipal solid waste produced in the year 2020 is estimated to be around 13.5 million tons. The daily amount of waste generation per capital is about $0.80 \mathrm{~kg} /$ person/day. Municipal/household waste accounts for about $90 \%$ of all households and the remaining $10 \%$ corresponds to other waste streams. Indeed, the amount of waste generated is affected by several factors, the most important of which are the city's population and its nature (commercial, industrial, etc.) [14].

Availability of accurate and reliable data on the composition of the waste is essential and crucial in evaluating and selecting appropriate waste treatment options. Waste composition, density, and moisture are important factors for managing treatment facilities and also affect the waste collection process.

In this context, in 2014 and 2018, the Agence National des Déchets (National Waste Agency) conducted two major national campaigns to determine the composition of the waste generated in Algeria. The campaign, which was launched in April 2018, took a year (until the end of March 2019) to monitor the differences in the composition of the composition on a quarterly basis (Figure 1). It aimed to accurately determine the composition of household waste and obtain updated data that would enable determining the most appropriate waste treatment methods or technologies [14].

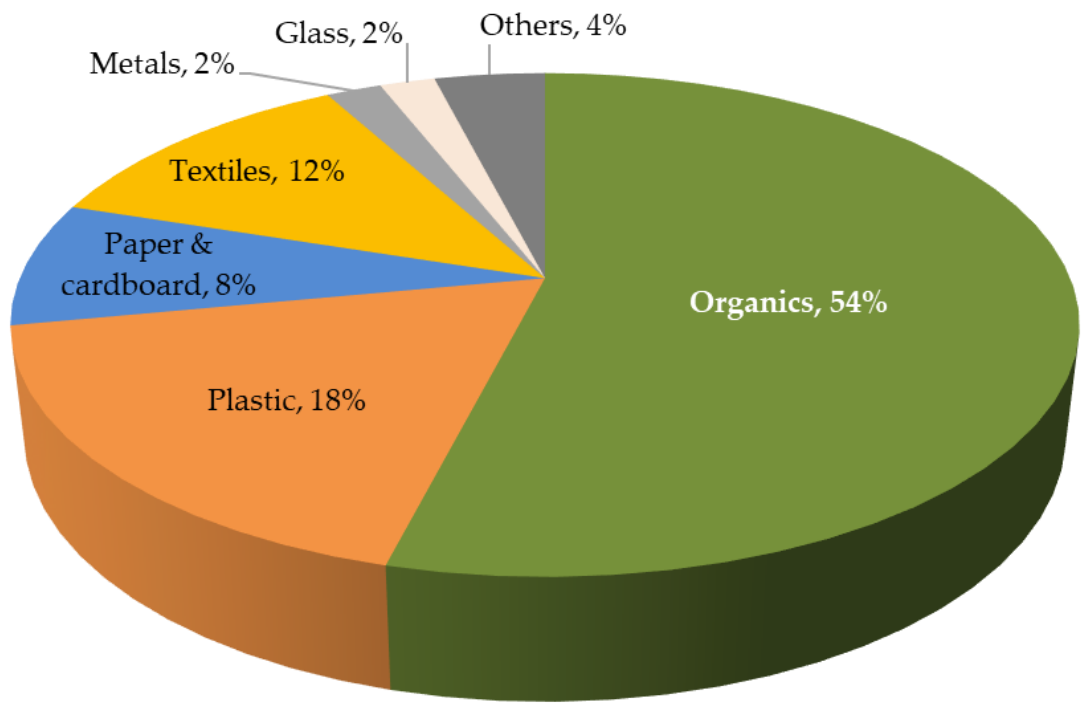

Figure 1. Average annual composition of MSW in Algeria [14].

The results show that organic materials dominate the waste composition, accounting for $54 \%$, followed by plastics $(18 \%)$, paper and cardboard $(8 \%)$, textiles $(12 \%)$, glass $(2 \%)$, metals $(2 \%)$, and other $(4 \%)$. Recently, a transition has been made from the common disposal practices applied in Algeria (illegal dumping) towards controlled sanitary landfills, which reflects a real awareness of environmental protection and the need for an integrated management of municipal solid waste. Currently, the waste generated in Algeria is served through 122 to 146 technical landfills, 32 controlled landfills, 29 sorting centers, and 54 Class 3 landfill technical centers (for inert waste), in addition to the rehabilitation of 40 unauthorized dumpsites [14].

Regarding the recycling activities at the national level, compared to other sectors, ferrous metals constitute the most important recycling sector, where the amount recovered annually is about 628,915 tons. This includes scrap, steel, and iron castings. 
As for the recycled plastic and paper and cardboard waste, the amounts are about 304,321 and 108,396 tons, respectively, annually. In addition, similar amounts of non-ferrous metals and wood are also recycled [14].

\subsection{Egypt}

Egypt generates around 26 million tons of MSW annually [15], thus representing almost one-third of the solid waste types generated in the country [16]. The MSW generation rates vary greatly between rural and urban areas. About $45 \%$ of the generated MSW comes from Greater Cairo (Cairo, Giza, and Qalioubiya governorates) and Alexandria, with a total population of 30.7 million generating 32,570 tons / day and with a collection efficiency between 50 and 70\%. These regions are followed by the Delta region consisting of the seven governorates of Beheira, Kafr El-Sheikh, Gharbia, Monufia, Sharqia, Dakahlia, and Damietta. This area has a total population of 36.4 million, which generates $30 \%$ of the total MSW (Figure 2).

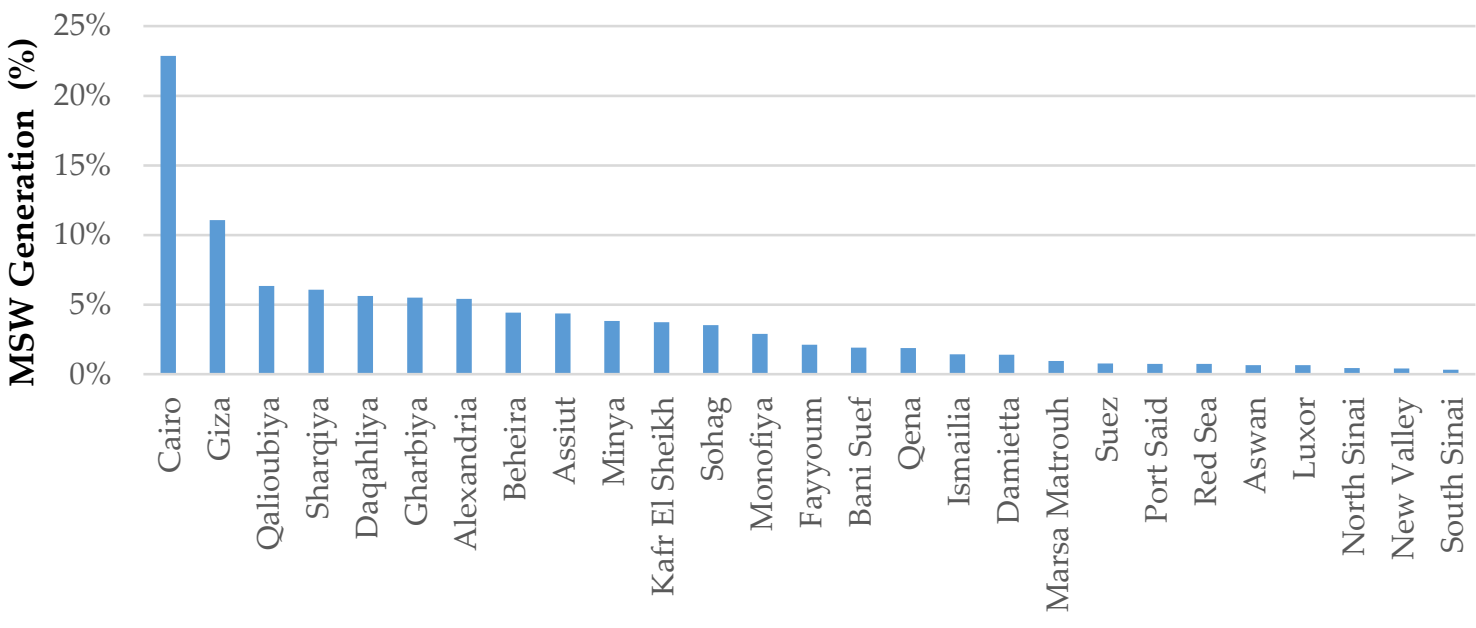

Egyptian Governorates

Figure 2. MSW generation distribution in Egypt [15].

The MSW collection coverage of the Delta region is only $50 \%$, as the area is challenged by the shortage of public land for waste treatment due to the agricultural activities and land ownership, leading to a great deal of waste being dumped on vacant land or agricultural drains, causing severe negative environmental and public health implications. Lastly, the other 16 governorates, with a population of 35 million, generate the remaining MSW, which represents $25 \%$ of the waste generated. On these bases, MSW generation rates across the Egyptian governorates vary between 0.3 and $2.0 \mathrm{~kg} /$ capita/day [17,18] (CAPMAS, 2021; MoE, 2020).

The MSW composition in Egypt is $56 \%$ organics, $13 \%$ plastics, $10 \%$ paper and cardboard, $4 \%$ glass, $2 \%$ metals, and 15\% other material [16], as shown in Figure 3 . However, MSW composition varies significantly across the different governorates, where the organic fraction can range between 41 and $70 \%$, plastic between 6 and 16\%, glass between 1.5 and $9.4 \%$, and metals between 1 and $8 \%$ [19]. 


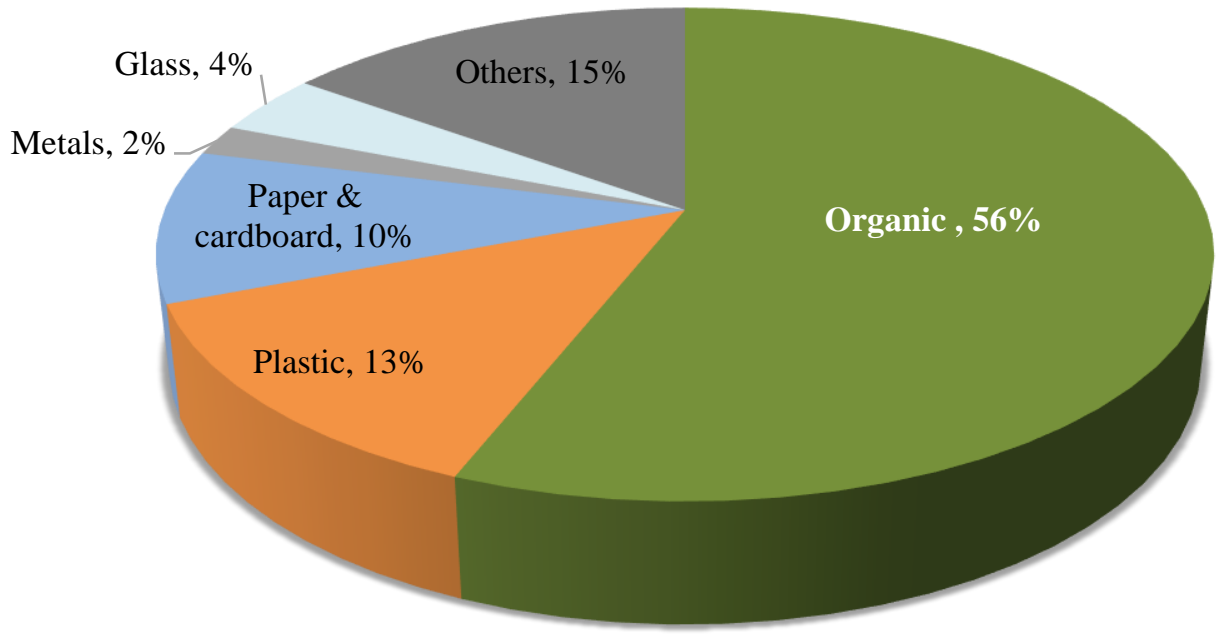

Figure 3. Average annual composition of MSW in Egypt.

Concerning the current waste management practices in Egypt, according to the most recent statistics issued by the Egyptian Ministry of Environment, MSW management in 2016 was based on open dumping (81\%), a small recycling share $(12 \%)$, and only $7 \%$ was landfilled [16]. Nevertheless, since its establishment in 2018, the Egyptian Waste Management Regulatory Authority (WMRA), has been working hard to improve its waste management status through enhancing recycling rates, by promoting composting, and RDF production. Currently, it is assumed that less than 10\% of the OFMSW generated in Egypt is composted as the process is not economically feasible [20], while for RDF production, the Egyptian government is seeking to encourage production and its utilization in cement plants [21].

\subsection{Jordan}

The solid waste generation in Jordan has been continuously increasing. However, due to the influx of Syrian refugees, the country has witnessed a sharp increase in the amount of solid waste generated [8,22]. The amount of solid waste collected in $2015(3,365,261$ tons) is greater by $24 \%$ than that collected in $2013[8,23]$.

As is the case in most developing countries, the solid waste generated in Jordan is mainly composed of organic materials. Figure 4 shows the composition of solid waste generated by different sources in the City of Irbid [22].

\subsection{Morocco}

Morocco generates 7.4 million tons of municipal solid waste annually. The solid waste generation per capita is estimated at $0.76 \mathrm{~kg} /$ day /capita and $0.3 \mathrm{~kg} /$ day /capita in urban and rural areas, respectively. About $70 \%$ of household waste produced in Morocco is organic, with a moisture content of $70 \%$, which causes the leachate problem. The proportion of recyclable waste ranges between 15 and $25 \%, 5-10 \%$ of which is paper and cardboard, $6-10 \%$ plastic, $1-4 \%$ metal, and $1-2 \%$ glass (Figure 5 ).

The total amount of organic waste in Morocco is estimated at 68.6 to 90.04 million tons annually including food industry, agricultural residues, wood residues, and other organic waste. Sewage sludge is estimated to be about 234,000 tons in 2020. The amounts of industrial waste and demolition and construction waste are about 5.4 million tons and 14 million tons, respectively. As for medical waste, it is about 21,000 tons/year, of which 6000 tons are hazardous waste [24]. 


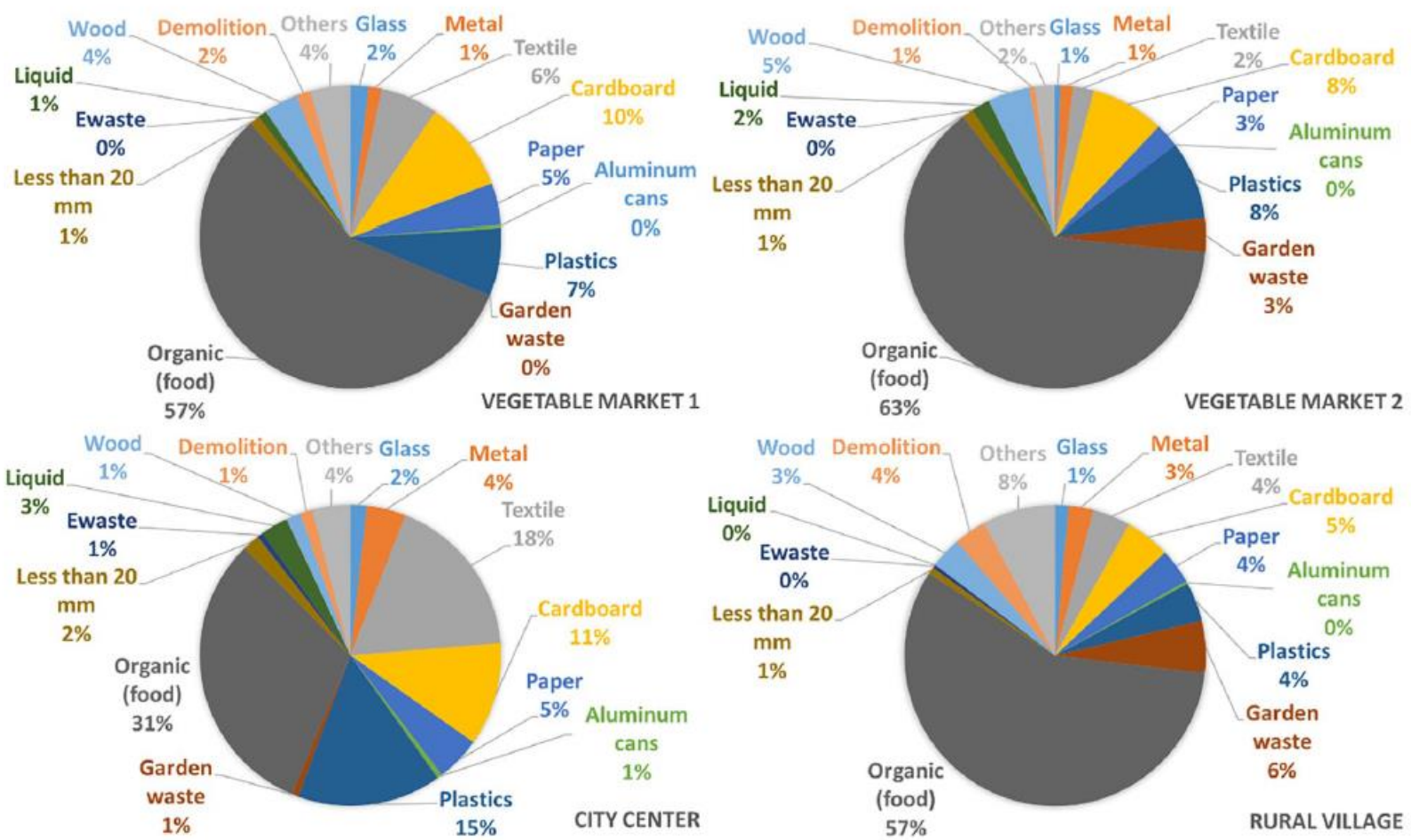

Figure 4. Solid waste composition generated by different sources in Irbid City, Jordan.

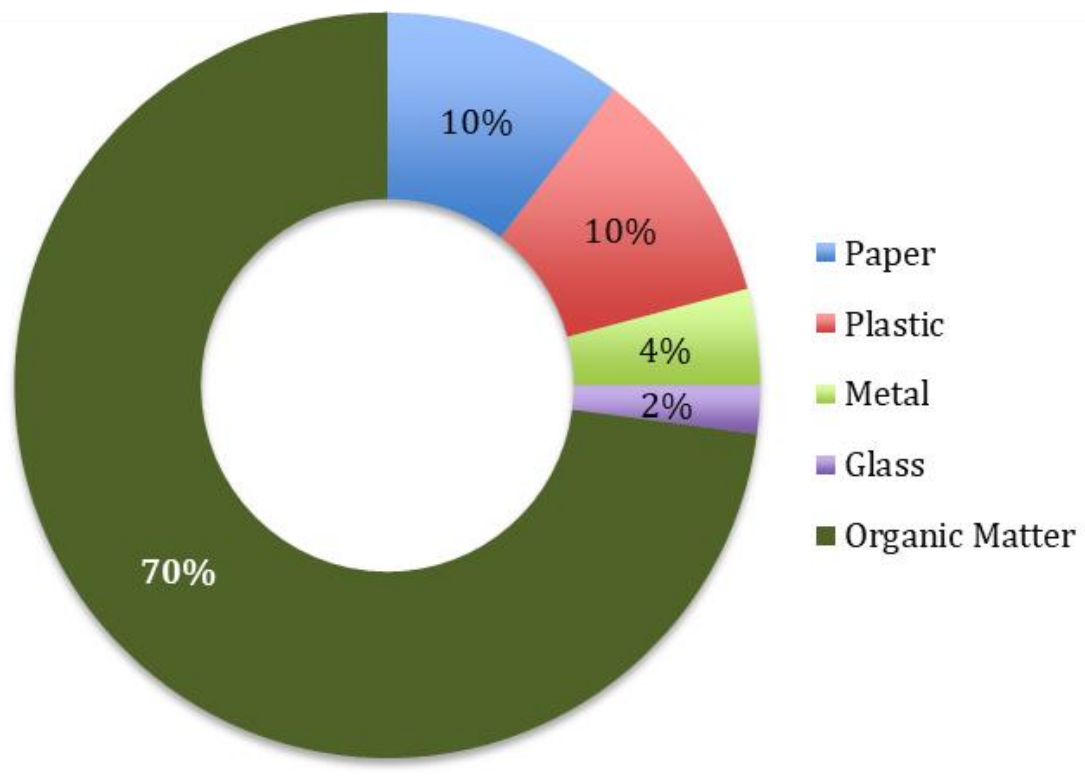

Figure 5. Solid waste composition generated by different sources in Morocco.

\section{Municipal Solid Waste-Management Practices}

Some waste management practices are more costly than others, and integrated approaches facilitate the identification and selection of low-cost solutions. Some waste management activities cannot bear any charges; some will always be net expenses, while others may produce an income. An integrated system can result in a range of practices that complement each other in this regard [25]. This means that the integrated solid waste management hierarchy cannot be followed strictly since, in particular situations, the cost of a prescribed activity may exceed the benefits, when all financial, social, and environmental considerations are taken into account. The MSW practices can be divided into four main activities: 
- Sorting and collection: Waste sorting is the process of separating MSW into different types. Waste sorting can occur before or after the waste is collected. The collection process involves collecting waste from households, from community and street bins, or from bulk generators in large containers or vehicles. It extends to activities such as driving between stops, idling, loading, and on-vehicle compaction of waste.

- Recycling: After waste sorting, recyclables are reprocessed into products.

- Transfer and transportation: This process involves the delivery of collected waste to transfer stations or treatment facilities.

- Treatment and disposal: Waste treatment is the process of disposing of waste after collection. Waste can be buried at landfills or burned through an incineration process. Non-recyclable waste items can be converted into compost or energy as various forms of useable heat, electricity, or fuel.

These four activities are used to examine and analyze the current solid waste management practices in the four selected MENA region countries, as described next.

\subsection{Algeria}

Up to $97 \%$ of the waste generated in Algeria is send to different controlled landfills and dumping sites without any pre-treatment, which generates high levels of methane gas due to the high amount of organic and water content. Specifically, $57 \%$ of the generated waste is disposed in open landfills or dumpsites, and $30 \%$ is being burned in uncontrolled open public or municipal landfills, while only $10 \%$ is disposed of in controlled or sanitary landfills (Figure 6). On the other hand, the rate of recyclable material recovery from the waste stream does not exceed $3 \%$; only $1 \%$ of the waste generated is recycled and $2 \%$ is subject to compost production [26]. It is clearly seen from Figure 6 that $87 \%$ of the generated waste is disposed of in open / uncontrolled dumpsites. According to a survey conducted by the Office of the Ministry of Regional Planning and Environment, more than 3130 surface dumps have been identified in the country, with a surface area of about 4552.5 hectares. Most of these dumps have almost reached their maximum capacity and cannot receive more waste [26].

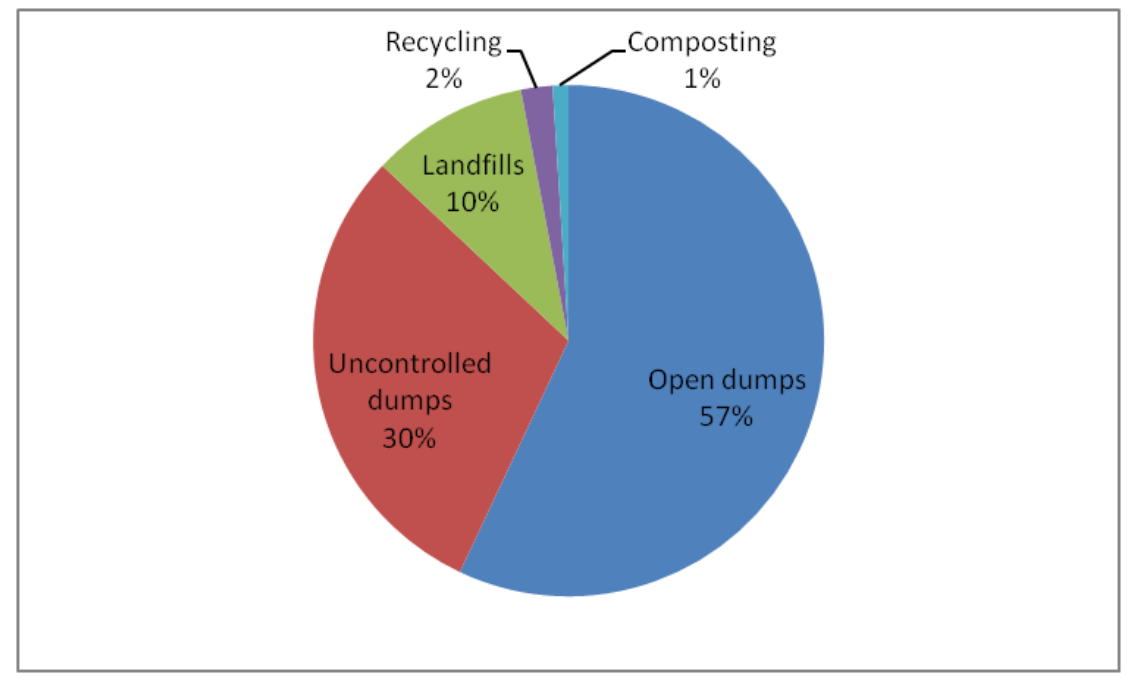

Figure 6. Methods of waste disposal in Algeria [27].

In 2001, the Algerian government decided to abandon the traditional model of waste disposal through open landfills and move towards the use of sanitary landfills. Accordingly, a plan was drawn up to establish 100 sanitary dumps, most of which were completed at the end of 2010 [27]. 


\subsection{Egypt}

Current waste management practices in Egypt do not include any source reduction or segregation programs. However, change in consumers' and residents' consumption patterns is often discussed as the cause of waste management challenges. These include increased waste-generation rates, increased use of single-use plastics, the difficulty of managing and treating mixed waste streams, inefficient use of resources, and, consequently, increased rates of pollution and environmental degradation $[16,28,29]$. However, recently, source reduction has been discussed extensively for managing single-use plastics, yet there have still been no source reduction measures implemented.

In terms of waste collection, the collection coverage was 20\% in 2015 and reaching a maximum of 70\% in Cairo city, the Egyptian capital. Improving waste collection is one of the main waste management plans in Egypt, which aims to reach $80 \%$ by the year 2030 . These goals are also associated with the African Union Commission's Agenda 2063, which calls for improving urban waste collection services to cover nine out of ten people by 2023 [28,30]. Waste collection in urban areas in Egypt is conducted through an integration of formal and informal sectors, where waste is formally collected from waste containers installed in the streets for a fee collected from residential and commercial units, as discussed earlier [18]. However, the informal sector offers a door-to-door collection service in the neighborhoods where the residents can afford to pay an extra fee for such services; recyclables are picked out from the collected waste before disposing of it in the formal waste management chain Generally, it can be assumed that the collection costs in Egypt represent between 50 and $80 \%$ of the MSW management costs.

According to the MSW collection system practiced in Egypt, most of the recycling activities are conducted through the informal sector and waste scavengers. The remaining waste in the formal waste management chain is commonly managed to produce compost and RDF, and to dispose of the rejects through landfilling and dumping. The OFMSW represents up to $70 \%$ of the MSW and its typical management approach is composting; however, that is challenged by the lack of appropriate compost quality that can comply with the environmental standards. Since there are no MSW source separation practices implemented in Egypt and MSW is collected as a mixed waste stream, there are substantial concerns about inadequately produced compost which comprises heavy metals that exceed the limitations of the Egyptian regulations [31,32]. Additionally, the process is not financially viable due to the compost's low sale value at 50-80 EGP per ton after production costs of up to EGP 200 [20]. Finally, for landfilling, Egypt is currently transitioning from disposing of waste in illegal dumpsites to controlled and sanitary landfills $[15,33]$.

\subsection{Jordan}

The waste sector in Jordan is governed by several national authorities including municipalities, the Ministry of Local Administration (MOLA), and the Ministry of Environment (MoEnv).

Currently, Jordan generates around 3.2 million tons per year. On average, Jordanians produce $0.81 \mathrm{~kg}$ of municipal waste per capita per day. Up to $90 \%$ of the solid waste generated in Jordan (approximately 2.1 million tons) is disposed of at one of the existing 17 operating landfills. The Ghabawi landfill is the only landfill in Jordan that meets international best practices. It was developed after a feasibility study. It has been subjected to an environmental-impact assessment, and meets international design and construction standards [5,34]. Currently, Al-Akeeder, which is the second-largest landfill in the country and serves the northern Jordan, is being subjected to rehabilitation activities, where the old cells are closed, while the newly opened cells are meeting sanitary landfilling standards.

Municipalities are directly responsible for the daily collection of waste, in addition to bearing the full costs of the process of collection, transportation, and disposal in landfills. This usually consumes $70 \%$ of the municipal budget allocated to waste management. Thus, these duties can affect the limited financial resources available to cover these costs, distracting from thinking about the indirect costs. 
The composition of municipal waste in Jordan is moving from a primarily organic mixture to a more complex mixture with more plastic, paper, and cardboard, as well as electronic waste. The composition of waste varies across the country, but in municipalities it is generally $51 \%$ organic, $15 \%$ plastic, and $14 \%$ paper. More than $50 \%$ of the waste generated by households is organic/food waste [9].

Recycling is still not practiced in Jordan on a formal level and the MSW is collected as mixed waste without any source separation activities. The solid waste recycling rate, which is $7 \%$, is low, even when compared to the average of $10 \%$ in the Gulf Cooperation Council (GCC) countries. Other waste types, such as agricultural waste [35], hazardous waste, medical waste [36], construction and demolition waste, and electronic waste are also generated in increasing volumes in Jordan, with insufficient means of treatment and disposal. In terms of environmental impact, landfill waste is an important component of Jordan's greenhouse gas emissions profile, contributing $10 \%$ of the country's total greenhouse gas emissions [34].

Recently, the government has started moving towards improved practices of solid waste landfilling by gaseous-emission reduction and leachate containment by both natural and synthetic liners. The Ministry of Local Administration is responsible for overseeing the implementation of the National Strategy and Action Plan (NSAP) for Municipal Solid Waste Management 2015-2034, which prioritizes mitigating environmental degradation through rehabilitation of dumpsites/unsanitary landfills, isolating the landfills by appropriate fences and buffer zones, adding sanitary linings to manage the leachate, and capping to reduce greenhouse gases (GHG) emissions.

\subsection{Morocco}

Nowadays, Morocco generates 7.4 million tons of municipal solid waste annually, 79\% of which is generated in urban areas. The per capita solid waste generation is estimated at $0.76 \mathrm{~kg} /$ day / capita and $0.3 \mathrm{~kg} /$ day/capita in urban areas and rural areas, respectively. However, the rate of solid waste production varies from city to city according to its nature and classification (residential, commercial, industrial, etc.). Taking into account the annual growth of municipal solid waste generation of about $1.36 \%$ and a collection rate of $96 \%$, the total amount of solid waste landfilled is estimated to be around 26.8 million tons. According to figures published in the National Strategy for Waste Reduction and Recovery in 2019, the amount of landfilled waste is expected to reach 39 million tons by 2030. In 2017 , the amount of household waste generated was about 4.7 million tons, in addition to 5.4 million tons of industrial waste and 14 million tons of construction and demolition waste [24].The amount of organic waste disposed in Morocco ranges between 68.6 and 90.04 million tons annually, including food industry, agricultural residues, wood residues, and other organic waste. The amount of industrial waste generated annually is about 5.4 million tons, in addition to 14 million tons of construction and demolition waste [24]. Organic waste dominates the waste composition, reaching about $70 \%$, with a high water content of about $70 \%$. The proportion of recyclable materials in the generated waste ranges between 15 and $25 \%$, of which $5-10 \%$ is paper and cardboard, $6-10 \%$ plastic, $1-4 \%$ metal, and 1-2\% glass. In terms of waste treatment and disposal, 25 disposal and recovery centers have been established since 2008. In the "Sorting, Recycling and Recovery" sector, priority is given to energy recovery from waste through anaerobic digestion, landfill gas production from sanitary landfills, incineration, and RDF utilization, while recycling is still in the initial stages [37]. Since the introduction of the National Program for Domestic Waste (PNDM) in 2008, Morocco has significantly improved the landfilling rate of domestic waste in controlled landfills, from 10\% before 2008 to $44 \%$ in 2015 [38]. The current recycling rate is presented in Table 3. The remainder of the collected waste is deposited in the 300 illegal landfills in the country. Similarly, the rate of waste collection, which is operated by private companies under a public service license, has increased from $44 \%$ in 2007 to $86 \%$ in 2015 . From a financial point of view, the collection costs in the municipal solid waste management budget are as royalty and range from 45 to 110 USD per ton, while landfilling costs range 
from 11 to 32 USD per ton [4,39]. Since the activation of the National Program for Domestic Waste (PNDM) in 2008, about 25 landfill and waste recovery (CEV) centers have been established across the country. A target of establishing 15 operational sorting centers in the CEVs by 2025, and 25 in 2030, has been set by the SNRVD. The first waste sorting center opened in September 2018 in Fez, ahead of the opening of the country's largest sorting center in Marrakesh. The production capacity of these facilities is between 300 and 768 tons of waste per day, which makes it possible to strengthen the sorting, recycling, and recovery channels required by the SNRVD and develop the capacity of local communities in terms of waste treatment $[24,39]$.

Table 3. Current recycling rate (2015 data) and new SNRVD objectives [24].

\begin{tabular}{clll}
\hline Recycling Rate Per Sector & $\mathbf{2 0 1 5}$ & $\mathbf{2 0 2 5}$ & $\mathbf{2 0 3 0}$ \\
\hline Plastics & $25 \%$ & $50 \%$ & $70 \%$ \\
Cardboard and Paper & $27 \%$ & $50 \%$ & $80 \%$ \\
Metals & $46 \%$ & $60 \%$ & $70 \%$ \\
Used oil & $36 \%$ & $50 \%$ & $40 \%$ \\
WEEE & $12 \%$ & $20 \%$ & $80 \%$ \\
Batteries & $30 \%$ & $50 \%$ & $80 \%$ \\
Tires & $42 \%$ & $60 \%$ & \\
\hline
\end{tabular}

\section{Comprehensive Analysis of Municipal Solid Waste-Management Systems}

\subsection{Legal and Financial Frameworks in Target MENA Region Countries}

One of the critical components that maintains the operation of highly advanced solid waste management systems is the government's ability to implement existing policies and regulations as well as develop and issue new regulations and laws in line with the requirements of the transition towards adopting sustainable solutions within the framework of waste management and the circular economy. Below is a detailed description of the most prominent laws and regulations covering waste management in the targeted countries in the MENA region.

\subsubsection{Algeria}

Since the 2000s, an important legal directive has been put in place to allow Algeria to respect the international commitments that the country has made and to ensure that environmental issues are addressed from a sustainable development perspective.

In Algeria, the task of municipal solid waste collection has been delegated to the municipalities by Law No. 01-19 of 12 December 2001 relating to waste management, control, and disposal. This law defines the basic principles that lead to the integrated management of waste, starting with its generation, followed by its collection, and ending with its treatment and disposal. Table 4 summarizes the Algerian legislative acts for municipal solid waste management [27].

In the waste management sector, Law 01-19 has been reinforced by several executive texts taking into account the following principles:

- Prevention of and reduction in the production and harmfulness of waste at the source;

- The organization of sorting, collection, transport, and treatment of waste;

- The recovery of waste by reuse, recycling, and any other action aimed at obtaining, from this waste, reusable materials or energy;

- The environmentally sound treatment of waste;

- Informing and raising citizens' awareness of the risks presented by waste and their impact on health and the environment, as well as the measures taken to prevent, reduce, or compensate for these risks [38]. 
Table 4. Algerian laws for municipal solid waste management [27].

\begin{tabular}{|c|c|}
\hline Law and Executive Decrees & The Related Field \\
\hline Law $\mathrm{N}^{\circ} \cdot 01-19$ & The management, control, and disposal of waste. \\
\hline Law $N^{\circ} \cdot 03-10$ & $\begin{array}{l}\text { The protection of the environment in the context of } \\
\text { sustainable development. }\end{array}$ \\
\hline $\begin{array}{l}\text { Executive decree } \\
\mathrm{N}^{\circ} .02-175\end{array}$ & The creation of the national waste agency. \\
\hline $\begin{array}{l}\text { Executive decree } \\
\mathrm{N}^{\circ} \cdot 04-410\end{array}$ & $\begin{array}{l}\text { The general rules for the development and operation of waste } \\
\text { treatment facilities and the admission of waste at } \\
\text { these facilities. }\end{array}$ \\
\hline $\begin{array}{l}\text { Executive decree } \\
\mathrm{N}^{\circ} \cdot 07-205\end{array}$ & $\begin{array}{c}\text { The modalities and procedures for the preparation, } \\
\text { publication, and revision of the scheme of municipal } \\
\text { household and similar waste management. }\end{array}$ \\
\hline $\begin{array}{l}\text { Executive decree } \\
\mathrm{N}^{\circ} \text {.04-199 }\end{array}$ & $\begin{array}{l}\text { The modalities for the establishment, organization, operation, } \\
\text { and financing of the public system of treatment and recovery } \\
\text { of packaging waste. }\end{array}$ \\
\hline
\end{tabular}

Several actors at both national and local levels are directly involved in waste management in Algeria. Among these are:

- The Ministry of the Environment through its various instruments, in particular the National Waste Agency, whose main mission is the accompaniment and support of organizations active in the waste management sector, in particular local communities (municipalities, collection operators, management institutions, etc.).

- The Ministry of the Interior, Local Authorities, and Regional Planning, which provides financial and logistical support to the Communal People's Assemblies by making annual grants. The amount reserved for urban waste management is quite significant.

Other ministries are also involved in the field of waste management. These include the Ministry of Health (dealing with medical waste), the Ministry of Industry (dealing with special hazardous waste), and the Ministry of Agriculture (dealing with agriculture waste and phytosanitary). Primarily, municipal waste management is the responsibility of local authority cleaning services (APC). This makes it difficult to control and monitor all phases of municipal solid waste: collection, transportation, treatment, and disposal of waste. In each city, a private company affiliated with the local authority is established, which is responsible for waste management in the concerned city, including the collection of fees. The primary role of local authorities is to supervise and monitor the performance of the private companies and ensure the cleanliness of cities. Despite the efforts made by the government, the participation of local communities in the field of waste management is still very limited. However, the average fee per person for household waste management (mainly collection and disposal) ranges from 4 to 7 USD/year [14].

\subsubsection{Egypt}

Egypt generates around 26 million tons of MSW annually, with generation rate varying significantly across the country. It has ambitious plans for improving the current MSW management systems [15]. To achieve these plans, numerous infrastructure waste management projects are being initiated, and a regulatory framework has been established. Law 202 for 2020 promulgating the Waste Management Regulation Law was issued on 13 October 2020 by the Egyptian Ministry of Environment. However, the executive regulation of the law has not yet been released. The law aims to develop the integrated management of municipal, industrial, agricultural, demolition, and construction waste as well as their safe disposal. The law also aims to reduce waste generation, promote reuse, and ensure the recycling, treatment, and final disposal of waste, and finally, to manage waste in a way that reduces damage to public health and the environment [18]. Concerning MSW, the new law does not include any articles calling for mandatory source separation nor prohibiting the landfilling of any specific waste streams or materials. 
The financial instruments applied for MSW management in Egypt involve a type of pay-as-you-throw fee. However, the fee is based on an estimated waste-generation rate that varies from one neighborhood to another across the different Egyptian cities and governorates where the MSW generation varies from 0.3 to $2.0 \mathrm{~kg} /$ capita/day. The new law states, in Article 34, that this fee ranges between 2 and 40 EGP per month per residential unit, 30 to 100 EGP for commercial units, up to 5000 EGP for governmental and community services establishments, and up to 20,000 EGP for commercial, industrial, and touristic establishments. Residential and commercial units are identified according to the number of electricity meters and, accordingly, the fees are collected with the electricity bills. Nevertheless, the fees collected only partly cover the waste management services' financial needs, which demand considerable municipal spending of approximately 7.2 billion EGP per year. Consequently, the new law, in Article 16, calls for extending the producers' responsibility to cover the end-of-life environmentally sound management and disposal costs of their products; yet, according to Article 17, the government shall issue a decree identifying priority products to be managed according to an Extended Producer Responsibility (EPR) financial scheme [18]. This has been proposed as a solution for the current financial challenges of waste management. The proposal relates to three waste streams that are extensively present in MSW, which are tires, packaging, and waste electrical and electronic equipment (WEEE) (Sustainable Recycling Industries, 2017). Furthermore, currently, the Egyptian government are working on establishing a strategy for EPR implementation for packaging waste, considering the different packaging materials available.

\subsubsection{Jordan}

Solid waste management within the urban and rural areas of the country is mainly implemented by municipalities. On the other hand, the disposal process into the sanitary landfills and dump sites (excluding Greater Amman Municipality) is undertaken by Joint Services Councils (JSCs), who own and operate 16 landfills. The JSCs are governmental agencies that are formed from several member municipalities located within one geographical region. They mainly deal with solid waste disposal $[34,40]$.

Until recently, Jordan had no special bylaw that regulated the solid waste generated in urban and rural centers of the country. However, in 2020, the Jordanian parliament passed the Waste Management Framework Law for the year 2020. This identified five basic principles of solid waste management, namely, prevention, the precautionary principle, extended producer responsibility, the polluter pays principle, and the proximity principle. Before passing the law, the Jordanian government endorsed the National Solid Waste Management Strategy, which established a road map to shift from a disposal driven (end of pipeline) solid waste management system into a more sustainable integrated system based on the reduce, reuse, and recycle approach.

The main institutions that are responsible for solid waste management include the Ministry of Environment (MoEnv), which is mainly concerned with the regulatory and policy aspects as well as monitoring of enforcement and compliance with these regulations. The Ministry of Local Administration (MOLA) is responsible for the supervision of the municipal functions and providing them with financial support. On the other hand, municipalities are responsible for the day-to-day work of solid waste management within their boundaries, which includes collection, transport, and transfer. Street sweeping is also part of the municipalities' work. The cemeteries are managed and operated by the JSCs. These are a consortium of a group of municipalities located in one geographic area and share the use of landfills to dispose of the solid waste generated by them [34].

\subsubsection{Morocco}

The primary objective of sustainable solid waste management is to address concerns related to public health, environmental pollution, land use, resource management, and the social and economic impacts associated with improper waste disposal. The main challenges facing the municipal solid waste management system in Morocco are the lack of appropriate 
infrastructure and adequate funding, especially in remote and small areas. Against these challenges, Morocco has taken several steps, engaged in an ambitious sustainable development agenda, and undertaken a wide range of reforms. Among those are the National Charter for Environment and Sustainable Development, the National Strategy for Sustainable Development 2015-2030, and the Nationally Determined Participation Commitments (INDC) through which Morocco commits to a $32 \%$ reduction in greenhouse gas emissions (GHG) by 2030. The framework is Law No. 99-12 on the National Charter for Environment and Sustainable Development. Morocco, like many other countries, has embarked on multiple regulatory and institutional approaches in this field of waste management by strengthening the legal arsenal that will serve as a framework for public authorities in this field. Law No. 28-00 on Waste Management and Disposal was promulgated to regulate waste management by covering the entire chain from collection to disposal, including treatment and recovery. For example, the Ministry of Energy, Mines and Environment is responsible for, among other treatments, treating waste by anaerobic fermentation method. The purpose of the law is to lay the foundations for a waste management policy, which in turn ensures the improvement of the performance of the management processes in force in addition to minimizing, as much as possible, the negative effects of waste on human health and the environment. The Moroccan Waste Code distinguishes between municipal waste, non-hazardous industrial waste, medical waste, pharmaceutical waste, agricultural waste, and hazardous waste, each of which falls under different planning and treatment regimes. Indeed, there are many laws and regulations in Morocco that regulate various aspects of waste management. Law 11-03 deals with the protection and development of the environment, while Law 12-03 focuses primarily on environmental-impact studies. A regulatory text for waste incineration activity was approved through Decree No. 2-12-172 issued in 2012, which specifies technical instructions related to waste removal and recovery operations by incineration. The disposal of plastic bags and their replacement with biodegradable bags is regulated in accordance with Law No. 22-10. Morocco consumes 26 billion plastic bags every year and the quota per capita is about 900 bags per year. In July 2016, Law No. 75-15 called "Zero Mika" came into force "which prohibits the manufacture, import, export, marketing, and use of plastic bags". On the other hand, Decree No. 2-09-139 regulates the management of medical and pharmaceutical waste in terms of the rules for sorting, packaging, collection, storage, transportation, and disposal. In Morocco, it is apparent that the actions implemented relate, in large part, to the use of landfill of waste in the absence of any approach aimed at reducing their production. Current practices for the implementation of the national municipal waste policy are represented mainly by the National Household Waste Program (PNDM). The Law 28-00 created an obligation for public inquiries for master, provincial, and landfill plans (Decree $\left.\mathrm{n}^{\circ} 2-09-683,2010\right)$. It sets out the modalities for the development of the regional master plan for the management of industrial, medical, pharmaceutical, non-hazardous, and agricultural waste. The National Waste Management Program is part of the policy of reforming and developing the municipal waste sector, which aims to structure this sector in local plans, especially by improving waste collection services, establishing waste treatment and recovery centers, and closing and rehabilitating old landfills. For hazardous waste, and in accordance with Article 9 of Law 28-00, a National Master Plan for Hazardous Waste (PDNDD) is being finalized in order to create an integrated and sustainable management system for hazardous waste. The National Charter for Environment and Sustainable Development (CNEDD) launched in 2009 consolidated the achievements of civil society participation at the local level and made it an important part of implementing the rule of law and legislation. After reviewing the most prominent laws regulating waste management in the target countries and in order to assess the situation more accurately, Table 5 summarizes the extent to which targeted MENA region countries apply the most prominent laws in force adopted by developed countries in the field of waste management and the circular economy. 
Table 5. The extent to which the targeted MENA region countries apply the most prominent laws in force adopted by developed countries.

\begin{tabular}{|c|c|c|c|c|}
\hline \multirow{2}{*}{ Regulatory Instruments } & \multicolumn{4}{|c|}{ Targeted MENA Region Countries } \\
\hline & Algeria & Egypt & Jordan & Morocco \\
\hline $\begin{array}{l}\text { Bans and Restrictions } \\
\text { (e.g., a landfill ban) }\end{array}$ & $\mathrm{N} / \mathrm{A}$ & $\mathrm{N} / \mathrm{A}$ & $\mathrm{N} / \mathrm{A}$ & $\mathrm{N} / \mathrm{A}$ \\
\hline $\begin{array}{c}\text { Mandatory Source } \\
\text { Separation }\end{array}$ & $\mathrm{N} / \mathrm{A}$ & $\mathrm{N} / \mathrm{A}$ & $\mathrm{N} / \mathrm{A}$ & $\mathrm{N} / \mathrm{A}$ \\
\hline \multicolumn{5}{|c|}{ Economic Instruments } \\
\hline $\begin{array}{l}\text { Extended Producer } \\
\text { Responsibility (EPR) }\end{array}$ & $\mathrm{N} / \mathrm{A}$ & Planning phase & Working on it & $\mathrm{N} / \mathrm{A}$ \\
\hline Deposit-Refund & $\mathrm{N} / \mathrm{A}$ & $\mathrm{N} / \mathrm{A}$ & $\mathrm{N} / \mathrm{A}$ & $\mathrm{N} / \mathrm{A}$ \\
\hline $\begin{array}{c}\text { Landfill/Incineration } \\
\text { Tax }\end{array}$ & $\mathrm{N} / \mathrm{A}$ & $\mathrm{N} / \mathrm{A}$ & Minimal & $\mathrm{N} / \mathrm{A}$ \\
\hline $\begin{array}{l}\text { Pay-As-You-Throw } \\
\text { (PAYT) }\end{array}$ & $\mathrm{N} / \mathrm{A}$ & Partially applied & $\begin{array}{l}\text { In Amman only. } \\
\text { Flat rate in } \\
\text { other cities }\end{array}$ & $\mathrm{N} / \mathrm{A}$ \\
\hline N/A: Not Available & & & & \\
\hline
\end{tabular}

It is clear from Table 5 that the region suffers from a lack of many laws and regulations, which, if they existed, would have contributed significantly to a qualitative leap in the waste management systems currently in use. Indeed, the first step that precedes the implementation of any waste management strategy or plan is the enactment of laws that support that strategy and ensure its success. Developed countries would not have reached their current advanced levels in the field of waste management and the circular economy without effective and strict laws. For example, Germany passed a law in June 2005 stating that waste can no longer be landfilled without pre-treatment, which in turn contributed to the transition from waste disposal to waste management. Reaping the fruits of this transformation took nearly 20 years of development and research. Therefore, all current laws in the region must be laid out for review and discussion with decision-makers in order to ascertain what is appropriate and to develop new laws that are compatible with the MENA region's circumstances and requirements.

\subsection{Waste Sorting and Collection}

Unlike high-income developed countries where there is public and societal awareness of waste sorting, sorting activities at the household level in developing countries, some of which are MENA region countries, are still limited and almost non-existent in some countries. Therefore, MSW generally consists of mixed waste containing food and other types of waste. Waste sorting is usually performed by poor families or the so-called informal sector in order to earn additional income from selling recyclable materials. Despite the high proportion of the municipal budget being spent on waste collection, about $80-90 \%$ of the total municipal solid waste budget, the efficiency of municipal solid waste collection is still very low in many countries, and this varies within the country itself. For example, in Jordan, the collection rate in Amman reaches 90\%, while in remote or rural areas, the efficiency of the collection process stands at $50 \%$, and sometimes less. Moreover, due to the low efficiency of waste collection, dumping of waste on the side of the road is a common practice and sometimes some of the public take up the task of burning waste in public places and on the roadside [40].

\subsection{Waste Treatment and Disposal}

Open dumping and landfilling are the most common methods of MSW disposal in developing countries, mainly because they are the cheapest treatment methods especially when social and environmental impacts are not considered. Together, these two methods account for about $70-90 \%$ of the total municipal solid waste. Compared with other treatment methods, open dumping and landfilling pose the highest risks to the environment 
and human health, causing deterioration in soil and water quality, air pollution, and the spread of diseases [34]. Recycling and material recovery activities are still in their initial stages due to the absence of supporting policies, regulations, and laws, in addition to the absence of public awareness of the importance of separating materials from the source. Incineration and energy recovery are very limited due to the high cost of investment and inappropriate composition of mostly inert and biodegradable waste that has high water content, which negatively affects the calorific value of waste. Composting has long been promoted as a method of treating biodegradable waste, creating new job opportunities and additional income generation for communities. However, many problems arise for composting practices. Composting run by municipalities often faces technical problems due to a lack of experience and know-how as well as the use of mixed MSW, which produces poor quality compost. Therefore, the application of composting practices is still limited to small or experimental projects, which are often unable to produce a market-oriented end product.

Despite most MENA region countries starting to improve their waste management services and adopting new strategies to achieve a sustainable waste management system by applying some advanced environmental technologies and expanding the scope of recycling and reuse, success is still limited, as the percentage of waste that is landfilled is still at its highest levels. This is clearly obvious from Table 6, which summarizes the practices adopted by the four countries covered by this study.

Table 6. Summary of the MSW practices adopted by the MENA region countries.

\begin{tabular}{|c|c|c|c|c|c|c|c|}
\hline \multirow[b]{2}{*}{ Country } & \multirow[b]{2}{*}{ Million Tons $y^{-1}$} & \multirow[b]{2}{*}{$\%$} & \multicolumn{4}{|c|}{ Treatment Method } & \multirow[b]{2}{*}{$\begin{array}{c}\text { WtE Rate } \\
(\%)\end{array}$} \\
\hline & & & $\begin{array}{c}\text { Landfilling } \\
\text { Rate }(\%)\end{array}$ & $\begin{array}{c}\text { Recycling } \\
\text { Rate (\%) }\end{array}$ & $\begin{array}{c}\text { Composting } \\
\text { Rate (\%) }\end{array}$ & $\begin{array}{c}\text { Anaerobic } \\
\text { Rate (\%) }\end{array}$ & \\
\hline Algeria & 13.5 & 100 & 92 & 7 & 1 & - & $\mathrm{N} / \mathrm{A}$ \\
\hline Egypt & 26 & 100 & 88 & 12 & $\begin{array}{l}\text { Incl. in } \\
\text { recycling }\end{array}$ & $\mathrm{N} / \mathrm{A}$ & $\mathrm{N} / \mathrm{A}$ \\
\hline Jordan & 3.2 & 100 & 90 & 10 & - & - & - \\
\hline Morocco & 7.4 & 100 & 91 & 9 & NA & NA & NA \\
\hline
\end{tabular}

The typical problems in municipal solid waste management in the region can be identified as insufficient collection systems, limited use of recycling and energy-recovery activities, and lack of know-how and skilled manpower.

Moreover, an overview of solid waste management practices in the four selected MENA countries is provided in Table 7 . It is quite clear that there are many problems in the handling, collection, transportation, treatment, and disposal of solid waste in the MENA region countries examined.

Table 7. Overview of MSW practices in the MENA region countries.

\begin{tabular}{|c|c|c|c|c|}
\hline \multirow{2}{*}{ Activity } & \multicolumn{4}{|c|}{ MENA Region Countries } \\
\hline & Algeria & Egypt & Jordan & Morocco \\
\hline $\begin{array}{l}\text { Source } \\
\text { reduction }\end{array}$ & $\begin{array}{l}\text { Discussions about source } \\
\text { reduction, but it is rarely } \\
\text { incorporated into any } \\
\text { organized plan. }\end{array}$ & $\begin{array}{l}\text { Unregulated, some discussions } \\
\text { about source reduction, but it is } \\
\text { rarely incorporated into any } \\
\text { organized plan. }\end{array}$ & $\begin{array}{l}\text { Discussions about source } \\
\text { reduction, but it is rarely } \\
\text { incorporated into any } \\
\text { organized plan. }\end{array}$ & $\begin{array}{l}\text { Structured educational } \\
\text { programs began to } \\
\text { emphasize source reduction } \\
\text { and material reuse. }\end{array}$ \\
\hline Collection & $\begin{array}{l}\text { Improving service and } \\
\text { increasing collection from } \\
\text { residential areas. Larger } \\
\text { vehicle fleet and more } \\
\text { mechanization. }\end{array}$ & $\begin{array}{l}\text { Intermittent and inefficient. } \\
\text { Improving service and } \\
\text { increasing collection from } \\
\text { residential areas. } \\
\text { Collection rate up to }>90 \% \text {. } \\
\text { Larger vehicle fleet. Compactor } \\
\text { trucks and highly mechanized } \\
\text { vehicles are common. }\end{array}$ & $\begin{array}{l}\text { Collection rate up to }>90 \% \text {. } \\
\text { Compactor trucks and } \\
\text { highly mechanized vehicles } \\
\text { are common. }\end{array}$ & $\begin{array}{c}\text { Improving service and } \\
\text { increasing collection from } \\
\text { residential areas. } \\
\text { Collection rate up to }>90 \% \text {. } \\
\text { Larger vehicle fleet. } \\
\text { Compactor trucks and } \\
\text { highly mechanized vehicles } \\
\text { are common. }\end{array}$ \\
\hline
\end{tabular}


Table 7. Cont.

\begin{tabular}{|c|c|c|c|c|}
\hline \multirow{2}{*}{ Activity } & \multicolumn{4}{|c|}{ MENA Region Countries } \\
\hline & Algeria & Egypt & Jordan & Morocco \\
\hline Recycling & $\begin{array}{l}\text { The informal sector is still } \\
\text { involved. Some high-tech } \\
\text { sorting and treatment } \\
\text { facilities. The material is } \\
\text { often imported for recycling. }\end{array}$ & $\begin{array}{l}\text { Most of the recycling is done by } \\
\text { the informal sector and } \\
\text { waste pickers. } \\
\text { Some high-tech sorting and } \\
\text { treatment facilities. The material } \\
\text { is often imported for recycling. } \\
\text { Increased interest in } \\
\text { long-term markets. }\end{array}$ & $\begin{array}{l}\text { Most of the recycling is done } \\
\text { by the informal sector and } \\
\text { waste pickers. }\end{array}$ & $\begin{array}{l}\text { The informal sector is still } \\
\text { involved. Some high-tech } \\
\text { sorting and treatment } \\
\text { facilities. The material is } \\
\text { often imported for recycling. }\end{array}$ \\
\hline Composting & $\begin{array}{l}\text { It is rarely conducted } \\
\text { formally even though the } \\
\text { waste stream has a high } \\
\text { organic matter content. }\end{array}$ & $\begin{array}{l}\text { It is rarely conducted formally } \\
\text { even though the waste stream } \\
\text { has a high organic } \\
\text { matter content. } \\
\text { Large composting plants are } \\
\text { usually unsuccessful; small } \\
\text { facilities are more sustainable. }\end{array}$ & $\begin{array}{l}\text { It is rarely conducted } \\
\text { formally even though the } \\
\text { waste stream has a high } \\
\text { organic matter content. }\end{array}$ & $\begin{array}{l}\text { Large composting plants are } \\
\text { usually unsuccessful; some } \\
\text { small composting facilities } \\
\text { are more sustainable. }\end{array}$ \\
\hline Incineration & $\begin{array}{l}\text { Some incinerators are used, } \\
\text { but they face financial and } \\
\text { operational problems. It is } \\
\text { not as common as in } \\
\text { high-income countries. }\end{array}$ & $\begin{array}{l}\text { They are not popular or } \\
\text { successful due to the high } \\
\text { CAPEX and OPEX costs, high } \\
\text { moisture content of the waste, } \\
\text { and high proportion of } \\
\text { inert materials. } \\
\text { Some incinerators are used, but } \\
\text { they face financial and } \\
\text { operational problems. It is not as } \\
\text { common as in } \\
\text { high-income countries. } \\
\text {-Predominant in areas where } \\
\text { land costs are high. Most } \\
\text { incinerators equipped with } \\
\text { environmental controls and } \\
\text { energy-recovery systems. }\end{array}$ & For medical waste only. & $\begin{array}{l}\text { Some incinerators are used, } \\
\text { but they face financial and } \\
\text { operational problems. It is } \\
\text { not as common as in } \\
\text { high-income countries. }\end{array}$ \\
\hline Landfilling & $\begin{array}{c}\text { Sanitary landfills equipped } \\
\text { with a combination of } \\
\text { linings, leak detection, } \\
\text { leachate collection, and } \\
\text { treatment systems. }\end{array}$ & $\begin{array}{l}\text { Low-tech sites. Open dumping } \\
\text { is still the most } \\
\text { practiced method. } \\
\text { Some controlled and sanitary } \\
\text { landfills equipped with a } \\
\text { combination of linings, leak } \\
\text { detection, leachate collection and } \\
\text { treatment systems. }\end{array}$ & $\begin{array}{l}\text { About } 70 \% \text { of the solid } \\
\text { waste generated goes to } \\
\text { sanitary landfills, while the } \\
\text { remainder is disposed into } \\
\text { unsanitary landfills. }\end{array}$ & $\begin{array}{l}\text { Some controlled and } \\
\text { sanitary landfills with some } \\
\text { environmental controls. } \\
\text { Open dumping is still the } \\
\text { most practiced method. }\end{array}$ \\
\hline Costs & $\begin{array}{l}\text { Collection costs account for } \\
80-90 \% \text { of the MSWM } \\
\text { budget. Fees for waste } \\
\text { management are regulated } \\
\text { by local governments. The } \\
\text { fee collection system } \\
\text { is inefficient. }\end{array}$ & $\begin{array}{l}\text { Collection costs account for } \\
\text { 80-90\% of the MSWM budget. } \\
\text { Fees for waste management are } \\
\text { regulated by local governments. } \\
\text { The fee collection system } \\
\text { is inefficient. }\end{array}$ & $\begin{array}{l}\text { Collection costs account for } \\
80-90 \% \text { of the MSWM } \\
\text { budget. Fees for waste } \\
\text { management are regulated } \\
\text { by local governments. The } \\
\text { fee collection system } \\
\text { is inefficient. }\end{array}$ & $\begin{array}{l}\text { Collection costs account for } \\
80-90 \% \text { of the MSWM } \\
\text { budget. Fees for waste } \\
\text { management are regulated } \\
\text { by local governments. The } \\
\text { fee collection system } \\
\text { is inefficient. }\end{array}$ \\
\hline
\end{tabular}

The waste management system in most MENA countries is limited to collection and transportation. During the past few decades, there has been a remarkable development in the solid waste collection and transportation system, but the recovery of materials and energy is still in its initial stages. Although these countries have tried to move towards a sustainable waste management system, their attempts have not brought about any lasting change as they were basically pilot initiatives or projects that ended when donor funding expired. This is due to the absence of planning, the use of inappropriate technology, and the inability of the municipalities to continue in light of their financial deficits. This indicates the urgent need to shift from poor management of municipal solid waste to a more effective and sustainable management system.

\section{Outlook from Selected MENA Region Countries}

\subsection{Algeria}

The general approach to solid waste management should be based on strengthening legislative and institutional frameworks, as is the case in developed countries. This includes 
public-private partnership (PPP) in waste management, and environmental, technical, and economic aspects of the processes used for treatment and recovery, in parallel with the adoption of a permanent education and awareness policy on waste management $[26,41]$. The management of urban solid waste is part of the National Action Plan for Environment and Sustainable Development (PNAE-DD) through the adoption of a National Program for Integrated Management of household waste (PROGDEM). It aims for an integrated, phased, and progressive management approach to household waste [41]. This program has defined the main directions for the implementation of this management through:

- The reorganization of the municipal administration responsible for waste management;

- Develop legislation and laws regulating waste management that promote recycling, energy and materials recovery, and reduce amount waste that ends up in landfills;

- Capacity building in the field of waste collection and transportation services;

- $\quad$ Providing an opportunity for private investment in the field of waste management and related public services;

- Implementation of training and technical assistance programs;

- Establish cooperation between the private and public sectors, which is required in order to ensure the technical, financial and social sustainability of the implemented solid waste management system.

\subsection{Egypt}

Egypt has ambitious plans to improve MSW management systems that are listed in Egypt Vision 2030. These involve increasing the waste collection coverage and efficiency from $20 \%$ and $60 \%$, respectively, in 2016 , to reach $80 \%$ and $90 \%$, respectively, by 2030 . The plans also include increasing the recycling rate to $25 \%$ by the year 2030 , as well as ensuring $100 \%$ safe disposal of hazardous wastes [28,42] (EEAA, 2018; MPED, 2016). Furthermore, WMRA has been working since 2018 towards increasing the collected MSW recycling rates to $80 \%$ by 2026 . Of this, $60 \%$ will be recycled for compost and RDF production, and $20 \%$ will be thermally treated for energy production. These plans are reinforced by numerous waste management infrastructure projects to build transfer stations, recycling plants, and sanitary landfills, as well as cleaning of waste accumulation sites, to cover the country completely in a four-year plan starting in 2019 [15,33]. The RDF production is being promoted by the Egyptian government, as the Ministerial Decree No. (49) of 2021 obliges cement plants to use a minimum of $10 \%$ RDF in the alternative fuels used for their energy requirements. The decree comes in response to the Ministry of Environment's plans to increase the waste-to-energy practices in cement plants to $15 \%$ by 2030 through the utilization of nearly 22 million tons of solid waste and 30 million tons of agricultural residues to produce RDF [21]. Moreover, waste-to-energy projects are being planned, relying on MSW through incineration, pyrolysis, and gasification. Minimization of singleuse plastics is also currently considered to be an MSW management focus area, as a response to the extremely high consumption of plastic bags in Egypt, which accounts for around 12 billion bags annually littering Egypt's streets and waterways [43]. Furthermore, numerous consultancy projects are currently being conducted to set strategies, guidelines, and roadmaps for improving MSW management through dumpsite closure, packagingwaste extended producer responsibility, and improving the management of other waste streams that are often present in the Egyptian MSW such as medical, electronic, construction, and demolition waste. These MSW management developments will be complemented with some important pillars including:

Introducing better definitions for waste management, practices, recycling, and recovery, to ensure that all the stakeholders are in agreement.

Inclusion of all the relevant formal and informal stakeholders in the formal development and plans for MSW management and ensuring their proper understanding of all the relevant regulations as well as national and international codes of design and practice. 
Promoting MSW source separation, as well as MSW waste stream separation from other waste streams commonly mixed with MSW through its management chain such as medical, industrial, construction, and demolition waste.

Developing business models for waste management interventions to encourage privatesector investment in MSW management.

\subsection{Jordan}

The national solid waste management strategy that was adopted by the Jordanian government in 2015 has established a road map for moving from the traditional end-ofpipeline technology towards a more sustainable and integrated solid waste management system [44].

Table 8 explains the proposed composting plants and their location and capacities according to the national solid waste management strategy.

Table 8. Proposed composting plants and their location and capacities according to the national solid waste management strategy [34,44].

\begin{tabular}{|c|c|c|c|c|}
\hline Region & $\begin{array}{l}\text { Governorate/ } \\
\text { Municipality }\end{array}$ & $\begin{array}{c}\text { Design } \\
\text { Capacity }\left(\text { ty }^{-1}\right)\end{array}$ & $\begin{array}{l}\text { Initial Starting } \\
\text { Amount }\left(t^{-1}\right)\end{array}$ & $\begin{array}{c}\text { Year of } \\
\text { Operation }\end{array}$ \\
\hline \multirow[b]{2}{*}{ Northern } & Irbid & 84,000 & 21,000 & 2025 \\
\hline & Mafraq & 22,000 & 5500 & 2025 \\
\hline \multirow{2}{*}{ Central } & Amman \& Zarqa & 215,000 & 53,750 & 2025 \\
\hline & $\begin{array}{l}\text { Salt Greater } \\
\text { municipality }\end{array}$ & 25,000 & 6250 & 2025 \\
\hline Southern & Aqaba & 25,000 & 6250 & 2025 \\
\hline
\end{tabular}

During the short and mid-term periods (until the year 2024) the strategy aims to convert the existing landfills into sanitary landfill sites. On the other hand, by the end of the long-term period (2025-2034), there should be the following facilities in operation:

- Three major clean material recovery facilities (MRFs);

- Two mechanical biological treatment facilities for mixed waste;

- Two anaerobic digestion units;

- $\quad$ Five composting plants.

\subsection{Morocco}

The national strategy predicts that the total amount of waste that will be landfilled by 2030 is about 39 million tons. The implementation of this strategy should reduce waste generation, increase material and energy recovery, and reduce environmental degradation associated with waste management. The cost was estimated at USD 0.5 billion or $0.4 \%$ of GDP. In order to encourage all companies involved in the waste management sector and the circular economy, the General Confederation of Moroccan Enterprises (CGEM) created in 2016 the Coalition for the Valorization of Waste (COVAD). An entrepreneurial dynamic was publicized on the occasion of the COP22, in particular via the Moroccan platform "Initiatives Climat", which identified and recounted personalized success stories. Two sectors were highlighted: anaerobic digestion and the production of organic biofuels.

In addition, Morocco introduced its first environmental tax (the ecotax) in 2014, consisting of $1.5 \%$ based on value when selling and importing plastics. Imposing this was not without struggle with the plastics industry. However, its proceeds now bring in USD 17 million to the National Environment Fund, which aims to finance the development of new recycling channels. Morocco highlighted its dedication to environmental protection and sustainability in the 2021 agreement of the United Nations Environment Assembly (UNEA), underlining its commitment to global cooperation in the name of a "green world". Morocco remains highly focused on environmental sustainability and the transition to green energy. The policy boasts a comprehensive plan to push Morocco into a "green economy" by 2030 through targeted investments, subsidies, and reforms. In Washington DC on 15 December 
2020, the World Bank Board of Executive Directors approved a USD 250 million (EUR 214.2 million) program to support the Moroccan agriculture sector's Green Generation Strategy, as part of a joint operation with the French Development Agency (AFD). The Green Generation Program-for-Results is designed to make farming more rewarding and strengthen sustainable agriculture by streamlining climate-smart practices.

\section{Summary}

Waste management in the MENA region is an extremely critical issue. Some years ago, significant changes occurred in the operational environment of the waste sector in the region due to the Arab Spring, which led to massive and sudden migration in many countries and a large influx of refugees. Jordan is one of those countries, for example. This has led to the creation of an additional environmental and economic problem represented by increasing pressure on infrastructure, greatly increased pollution, and rapid urbanization, which negatively affects the waste management system in the host countries.

However, this work has shown that some countries have already begun to improve their waste management service and have adopted new strategies to achieve a sustainable system within the framework of waste management and the circular economy. Indeed, some countries have implemented some advanced environmental technologies and expanded the scope of recycling and reuse. Nevertheless, this progress has been quite limited and unsustainable, and did not go beyond the level of pilot projects, which often ended when funding expired.

On the other hand, this work shows that the solid waste sectors in the MENA region suffer from critical problems and face many challenges in terms of waste management and the techniques applied to improve it. The typical problems in MSW management in the region can be identified as the increase in per capita MSW generation rates, the gaps in current related legislation, financial constraints, lack of know-how, limited material and energy-recovery activities, insufficient collection systems, and lack of trained and skilled manpower. Therefore, it was clear from the study that waste management challenges in the region are common and similar. They can be summarized, but are not limited, as follows:

The lack of legislation and weak implementation are considered two of the main challenges facing waste management in the MENA region countries. Furthermore, the lack of tools to assess and monitor the performance of waste treatment technologies and their output quality and utilization is considered one of the main problems.

The low level of cooperation between national institutions and local authorities, and the overlapping roles. Governments should define roles, prioritize responsibilities, and develop regulations to ensure a harmonized framework.

There is an urgent need to review and reform the waste management sector to improve its services in many countries in the region. Most waste sectors in the region have central waste management in terms of planning and defining tariffs, regulations, and laws that regulate waste management systems, which can be developed by decentralizing these sectors and giving municipalities powers that enable them to provide a better service.

The impact of refugee flows due to political instability in the Middle East and North Africa region, which has burdened the waste sectors and doubled the pressure on the infrastructure.

The limited participation of the national private sector in decision-making and developing plans and strategies in waste management in most countries of the Middle East and North Africa. There is an urgent need in most MENA countries for private-sector participation and investment in the waste management sector to achieve the sustainable development goals.

Limited funding sources and their negative impact on the quality of waste management and the sustainability of projects in the region. The fees collected for managing waste are very low, covering no more than $30 \%$ of the costs. The funding system for waste management is unequally distributed, as $90 \%$ of the funds available go to logistics and only $10 \%$ remains for treatment. Therefore, work, should be done to strengthen and empower 
the municipalities so that they are able to develop and implement sustainable solutions that are compatible with their circumstances and capabilities.

Separate collection is still not practiced in the region. The MSW is collected as mixed waste and contains hazardous materials. Up to $90 \%$ of it is sent to different controlled landfills and dumping sites without any treatment, which generates high levels of methane gas due to the high amount of organic material and water content. The rate of recyclable material recovered from the waste stream is about $5-10 \%$.

Indeed, most of the approaches undertaken in the past have included the adoption of treatment and disposal technologies without a full understanding of the process, which has led to the lack of knowledge and local skilled manpower. All of these issues emphasize the weaknesses and problems in the previous measures. In order to overcome these problems, first, a technical solution should be developed with the required modifications and proper implementation considering the legal, financial, and management aspects.

\section{Recommendations}

The governments must promote an integrated solid waste management hierarchy and set up a national policy regarding the minimization of waste to landfill by making a shift from waste disposal towards waste management and the circular economy.

Attention should be paid to increasing coordination and linking governmental bodies, institutions, and services at the administrative and legislative levels to improve management in terms of waste collection, treatment, and disposal.

Establish more cooperation between local waste management authorities and different ministries responsible for various policies including waste management, energy, and the environment in order to explore the full potential of implementing a sustainable waste management system that adopts a holistic approach.

It is essential that local industry and educational institutions have regular links with waste management regulatory bodies. This can be facilitated by creating a network platform that brings together all stakeholders in the waste management sector.

A network concerned with waste management should be created at the level of the countries of the MENA region for the various member states to share their experiences in the research and development of innovative technology to reveal the potential in the recycling industry and convert waste into energy and any regulatory framework to accommodate it.

Reconsider the waste management fee system through the establishment of the extended product responsibility system.

Establish cooperation between the private and public sectors involved in the solid waste management system and the circular economy in order to ensure the technical, financial, and social sustainability of the solid waste management system implemented.

Cooperate with universities and research institutions in order to support municipalities facing challenges, provide sustainable solutions, and develop plans to improve the waste management system and provide better services.

Launch large-scale awareness programs on solid waste management and the circular economy for all citizens and stakeholders. Work on developing preventive measures represented by adopting environmentally responsible behaviors and attitudes that make it possible to carry out sorting, selective collection, and recovery of materials and energy from waste.

\section{Conclusions}

Solid waste management has become one of the major environmental problems facing municipal authorities in the MENA region. It has been aggravated over the past few years by the sharp increase in the volume of waste generated as well as qualitative changes in its composition. The provision of adequate waste management services is critical because of the potential impact on public health and on the environment. Lack of planning, lack of proper disposal, insufficient collection services, use of inappropriate technology, inadequate financing, and limited availability of trained and qualified manpower together with massive 
and sudden population increases are considered to be the main problems facing solid waste management in the region.

The aim of this study was to identify the different practices and approaches of solid waste management employed in selected MENA region countries, and the extent to which the policies, regulations, and technologies applied play any role in the context of solid waste management and the circular economy.

The study revealed that most waste management issues in the countries analyzed appear to be due to political factors and the decentralized nature of waste management with multi-level management and responsibilities. Material and energy recovery in the context of municipal solid waste management does not differ significantly in the countries in the MENA region considered; in most cases, "waste" is still seen as "trouble" rather than a resource. Therefore, a fresh look is required and there is a need for a paradigm shift from a linear economy of "waste management", to a circular-economy model of "resource efficiency". The latter can be achieved by adopting a joint vision on how the solid waste management system can be transformed into a circular economy. Since they are the main drivers of any transition towards a circular-economy system, the policies, strategies, and practices in place that regulate the performance of waste management in the region must be revised.

For fairness, despite the financial and technical obstacles facing the waste management sector, continuous attempts are made to divert waste from landfills to some advanced recycling facilities. Indeed, most countries in the MENA region are approaching sustainable waste management solutions and most decision makers do identify their problems and previous mistakes for setting a solid waste management system. Currently, there is a consensus among the concerned authorities in the region that the success of any sustainable waste management solution requires the involvement and cooperation of all parties involved in the sector such as international companies, local private companies, and municipalities. Awareness is also being raised regarding the necessity of shifting towards the implementation of waste management in the context of a circular economy.

Author Contributions: Conceptualization, S.H. and O.A.; methodology, S.H.; validation, S.H., O.A., L.E.F., S.E., I.H. and J.G.; investigation, S.H., O.A., L.E.F. and S.E.; resources, S.H., O.A., L.E.F., S.E., M.H., B.C. and M.A.; data curation, S.H. and O.A.; writing-original draft preparation, S.H., O.A., L.E.F. and S.E; writing-review and editing S.H.; visualization, S.H.; supervision, S.H.; project administration, S.H., I.H. and J.G.; funding acquisition, S.H. All authors have read and agreed to the published version of the manuscript.

Funding: This research funded by the PREVENT Waste Alliance, an initiative of the German Federal Government in the framework of the German-MENA University Network for Waste Management and Circular Economy project (Grant number 81263215).

Data Availability Statement: Not applicable.

Acknowledgments: This research was carried out within the framework of the German-MENA university network for waste management and circular economy project, which is funded by the PREVENT Waste Alliance, an initiative of the German Federal Government.

Conflicts of Interest: The authors declare no conflict of interest.

\section{References}

1. EIA. Countries Profile, Middle East and North Africa; U.S. Energy Information Administration: Washington, DC, USA, 2015.

2. World Bank. Population, Total-Middle East and North Africa. 2020. Available online: https://data.worldbank.org/indicator/SP. POP.TOTL?locations=ZQ (accessed on 20 October 2021).

3. Onwosi, C.; Igbokwe, V.; Odimba, J.; Eke, I.; Nwankwoala, M.; Iroh, I.; Ezeogu, L. Composting technology in waste stabilization: On the methods, challenges and future prospects. J. Environ. Manag. 2017, 190, 140-157. [CrossRef] [PubMed]

4. Negm, A.M.; Shareef, N. (Eds.) Introduction to the Waste Management in MENA Regions. In Waste Management in MENA Regions; Springer Water; Springer International Publishing: Cham, Switzerland, 2020; pp. 1-11. ISBN 978-3-030-18350-9.

5. Hemidat, S. Feasibility Assessment of Waste Management and Treatment in Jordan. Ph.D. Thesis, The Academic Board of Rostock University, Rostock, Germany, 2019. 
6. Abu-Qdais, H.; Gibellini, S.; Vaccari, M. Managing Solid Waste under Crisis: The Case of Syrian Refugees in Northern Jordan. In Proceedings of the Sardinia 2017-Sixteenth International Waste Management and Landfill Symposium, Cagliari, Italy, 2-6 October 2017.

7. Nassour, A.; Al-Ahmad, M.; Elnaas, A.; Nelles, M. Practice of waste management in the Arab region. Contribution in: Water-toresources 2011-4. In Proceedings of the International Conference MBT and Sorting Systems, Hanover, Germany, 24-26 May 2011; Kule-weidemeier, M., Ed.; pp. 81-91.

8. Abu-Qdais, H.; Wuensh, C.; Dornack, C.; Nassour, A. The role of solid waste composting in mitigating climate change in Jordan. Waste Manag. Res. 2019, 37, 833-842. [CrossRef] [PubMed]

9. Hemidat, S.; Saidan, M.; Al-Zu'bi, S.; Irshidat, M.; Nassour, A.; Nelles, M. Potential Utilization of RDF as an Alternative Fuel for the Cement Industry in Jordan. Sustainability 2019, 11, 5819. [CrossRef]

10. Karak, T.; Bhagat, R.M.; Bhattacharyya, P. Municipal solid waste generation, composition, and management: The world scenario. Crit. Rev. Environ. Sci. Technol. 2012, 42, 1509-1630. [CrossRef]

11. Chaher, N.E.H.; Chakchouk, M.; Nassour, A.; Nelles, M.; Hamdi, M. Potential of windrow food and green waste composting in Tunisia. Environ. Sci. Pollut. Res. 2020, 28, 46540-46552. [CrossRef] [PubMed]

12. Chaher, N.E.H.; Hemidat, S.; Thabit, Q.; Chakchouk, M.; Nassour, A.; Hamdi, M.; Nelles, M. Potential of Sustainable Concept for Handling Organic Waste in Tunisia. Sustainability 2020, 12, 8167. [CrossRef]

13. Boudghene Stambouli, A. Algerian renewable energy assessment: The challenge of sustainability. Energy Policy 2011, 39, 4507-4519. [CrossRef]

14. AND—Agence National des Déchets (National Waste Agency). 2020 Rapport sur L'état de la Gestion des Déchets en Algérie; AND: Algiers, Algeria, 2020.

15. MoE-Ministry of Environment. Municipal Solid Waste Management System "Infrastructure"; MoE: Cairo, Egypt, 2021.

16. EEAA. Egypt State of the Environment Report; EEAA: Chatswood, Australia, 2017.

17. CAPMAS. Population of Egypt. Central Agency for Public Mobilization and Statistics. 13 July 2021. Available online: https: //www.capmas.gov.eg/Pages/populationClock.aspx\# (accessed on 25 September 2021).

18. MoE-Ministry of Environment. Law 202 for 2020 Promulgating the Waste Management Regulation Law; MoE: Cairo, Egypt, 2020.

19. Abdallah, M.; Arab, M.; Shabib, A.; El-Sherbiny, R.; El-Sheltawy, S. Characterization and sustainable management strategies of municipal solid waste in Egypt. Clean Technol. Environ. Policy 2020, 22, 1371-1383. [CrossRef]

20. Enterprise. Where did Things go Wrong with Egypt's Waste Management? Enterprise: Aliso Viejo, CA, USA, 2020.

21. CemNet. Egypt: Cement Plants to Use 15\% of Waste by 2030. 2016. Available online: https://www.cemnet.com/News/story/16 0444/egypt-cement-plants-to-use-15-of-waste-by-2030.html (accessed on 12 September 2021).

22. Gibellini, S.; Abu Qdais, H.; Vaccari, M. Municipal solid waste management in refugee hosting communities: Analysis of a case study in northern Jordan. Waste Manag. Res. 2021, 0734242X21994656. [CrossRef] [PubMed]

23. DOS-Department of Statistics. Jordan in Figures; Department of Statistics: Amman, Jordan, 2017; pp. 33-34.

24. SNRVD. National Waste Reduction and Recovery Strategy. Summary Report. 2019. Available online: https://www.logipro.ma/ images/Traitement_des_deee/Rapport_de_synthese_SNRVD_FR.pdf (accessed on 10 August 2021).

25. UNEP. Integrated Waste Management Scoreboard-A tool to Measure Performance in Municipal Solid Waste Management; UNEP: Nairobi, Kenya, 2005.

26. Djemaci, B.; Ahmed Zaïd, M. Integrated Solid Waste Management in Algeria. Constraints and Limits of Its Implementation; CIRIEC Act 12; CIRIEC: Liège, Belgium, 2011.

27. Kouloughli, S.; Kanfoud, S. Municipal Solid Waste Management in Constantine, Algeria. J. Geosci. Environ. Prot. 2017, 5, 85-93. [CrossRef]

28. EEAA. State of the Environment 2017-Summary for Policymakers; EEAA: Chatswood, Australia, 2018.

29. UNEP. National Action Plan for Sustainable Consumption and Production (SCP) in Egypt; UNEP: Nairobi, Kenya, 2016.

30. African Union. AGENDA 2063: The Africa We Want-First Ten-Year Implementation Plan; African Union: Addis Ababa, Ethiopia, 2015.

31. Smith, S. A critical review of the bioavailability and impacts of heavy metals in municipal solid waste composts compared to sewage sludge. Environ. Int. 2009, 35, 142-156. [CrossRef] [PubMed]

32. WMRA. Egyptian Code of Design Principal and Implementation Conditions for Municipal Solid Waste Management Systems; WMRA: Harrisonburg, VA, USA, 2019.

33. Youm7. Egypt's New Waste Management System. 2021. Available online: www.youm7.com/story/2021/2/13/\%D9\%85\% D8\%B5\%D8\%B1-\%D8\%AA\%D8\%AA\%D8\%AC\%D9\%85\%D9\%84-\%D9\%85\%D9\%86\%D8\%B8\%D9\%88\%D9\%85\%D8\%A9-\% D8\%A7\%D9\%84\%D9\%85\%D8\%AE\%D9\%84\%D9\%81\%D8\%A7\%D8\%AA-\%D8\%A7\%D9\%84\%D8\%B5\%D9\%84\%D8\%A8\%D8 \%A9-\%D8\%A7\%D9\%84\%D8\%AC\%D8\%AF\%D9\%8A\%D8\%AF\%D8\%A9-\%D8\%AA\%D8\%B3\%D9\%8A\%D8\%B1-\%D8\%B9\%D9 \%84\%D9\%89-\%D9\%82\%D8\%AF\%D9\%85-\%D9\%88\%D8\%B3\%D8\%A7\%D9\%82/5204062 (accessed on 13 September 2021).

34. MoEnv-Ministy of Environment. Waste Sector Green Growth National Action Plan 2021-2025; The Hashemite Kingdom of Jordan: Amman, Jordan, 2020.

35. Abu-Ashour, J.; Abu Qdais, H.; Al-Widyan, M. Estimation of animal and olive 219 solid wastes in Jordan and their potential as a supplementary energy source: An overview. Renew. Sustain. Energy Rev. 2020, 14, 2227-2231. [CrossRef]

36. Abu-Qdais, H.A.; Al-Ghazo, M.A.; Al-Ghazo, E.M. Statistical analysis and characteristics of hospital medical waste under novel Coronavirus outbreak. Glob. J. Environ. Sci. Manag. 2020, 6, 1-10. [CrossRef] 
37. El Jalil, M.H.; Elkrauni, H.; Khamar, M.; Bouyahya, A.; Elhamri, H.; Cherkaoui, E.; Nounah, A. Physicochemical characterization of leachates produced in the Rabat-Salé-Kénitra Region landfill technical center and monitoring of their treatment by aeration and reverse osmosis. E3S Web Conf. 2020, 150, 02013. [CrossRef]

38. World Bank. What a Waste 2.0. A Global Snapshot of Solid Waste Management to 2050; World Bank: Washington, DC, USA, 2018. [CrossRef]

39. The Climate Chance Observatory Team. Moroccan Society's Uneven Response to the Proliferation of Waste. Case Study Morocco; The Climate Chance Observatory Team: Paris, France, 2019.

40. Hemidat, S.; Oelgemöller, D.; Nassour, A.; Nelles, M. Evaluation of key indicators of waste collection via GIS techniques as a planning and control tool for route optimization. Waste Biomass Valorization 2017, 8, 1533-1554. [CrossRef]

41. Cooperation GIS. Report on the Solid Waste Management in Algeria; Cooperation GIS, SWEEP-Net: Algiers, Algeria, 2014.

42. MPED. Egypt Vision 2030; MPED: Cairo, Egypt, 2016.

43. UNEP. Reducing Plastic Bag Consumption in Egypt: SwitchMed in Egypt-Factsheet; UNEP: Nairobi, Kenya, 2020.

44. MOLA; CVDB. Ministry of Local Affairs Report, Jordan. Development of a National Strategy to Improve the Municipal Solid Waste Management Sector in the Hashemite Kingdom of Jordan; Report on the Implementation Arrangements for the Recommended MSWM Strategy in the Hashemite Kingdom of Jordan (3rd Draft Report); Consultants: LDK, MOSTAQBAL; Ministry of Local Affairs: Amman, Jordan, 2014. 